\title{
Immigration as practice of organization: discussions about practices of organization, displacement, and integration of Haitian immigrants in the Goiânia Metropolitan Region, in Goiás, Brazil
}

\author{
GABRIEL do CARMO YAMAMOTO ${ }^{1}$ \\ JOSIANE SILVA DE OLIVEIRA ${ }^{2}$
}

\author{
${ }^{1}$ Universidade Estadual de Maringá (UEM) / Graduate Program in AdMinistration, Maringá - PR, BraziL \\ 2 UNIVERSIDAde ESTADUAL de MARINGÁ (UEM) / DEPARTMENT OF ADMINISTRATION AND CENTER OF AFRO-BRAZILIAN INTERDISCIPLINARY \\ STUDIES, MARINGÁ - PR, BRAZIL
}

\begin{abstract}
This study aims to discuss the practices of displacement and organization that are part of the process of integrating Haitian immigrants in the countries that they live, in their diaspora process. Haiti is a country historically marked by displacement, which is observed since the colonial period, when people were forcibly displaced to be enslaved. This article will focus on the process of displacement, through the theoretical lens of Practice-Based Studies, using Michel de Certeau's theory about social practices, associated with the concepts of Tim Cresswell about displacement and immigration as practice. The research was conducted between August and December 2017 in two Haitian communities in the Goiânia Metropolitan Region, in the state of Goiás, located in Central-West Brazil. For the production of empirical material, we used the techniques of life history interview and participant observation, by accompanying the everyday life activities in the immigrant's communities. The results show that the practice of displacement of Haitian immigrants is an unfinished and still in process phenomenon, involving different dimensions of events, with international, national, and commuting displacement. It was also possible to conclude that the displacement practices are permeated by organizational practices and that "organizing" and "migrating" are processes involved. In addition, the practice of organization is a key component for integration and access to the workplace in Brazil. Therefore, immigration can be considered sets of practices to organize mobility experiences that are spatially multi-localized and incorporated.
\end{abstract}

Keywords: Organization. Displacement. Haitian Immigrants. Social Practice.

\section{Imigração como prática de organização: discussões sobre práticas de organização, deslocamento e integração} de imigrantes haitianos na Região Metropolitana de Goiânia, em Goiás, Brasil

\section{Resumo}

Esse estudo busca conduzir discussões sobre as práticas de deslocamento e organização, que são parte do processo de integração de imigrantes haitianos nos países em que vivem, em seu processo de diáspora. Haiti é um país historicamente marcado pelo deslocamento, a exemplo das pessoas que foram forçadamente deslocadas para serem escravizadas no período colonial do país. Portanto, esse estudo focará no processo de deslocamento, por meio da lente teórica dos Estudos Baseados em Prática, fazendo uso de Michel de Certeau, que teoriza sobre práticas sociais, associadas a conceitos de Tim Cresswell sobre deslocamento e imigração como prática. A pesquisa foi conduzida entre agosto e dezembro de 2017 em duas comunidades haitianas na Região Metropolitana de Goiânia, Goiás, localizada no Centro Oeste do Brasil. Para a produção de material empírico nós usamos a técnica de história de vida e observação participante, aplicadas no acompanhamento das atividades cotidianas das comunidades de imigrantes. Como resultados principais foi obtido que a prática de deslocamento de imigrantes haitianos é um fenômeno em que o processo não está acabado e que ainda ocorre, envolvendo diferentes dimensões de eventos, com os deslocamentos internacional, nacional e pendular. Também foi possível concluir que práticas de deslocamento são permeadas por práticas organizacionais, sendo o "organizar" e "migrar" processos envolvidos. Ademais, a prática de organização é um componente-chave para a integração e acesso ao local de trabalho no Brasil. Portanto, a imigração pode ser considerada um conjunto de práticas para organizar experiencias de mobilidade que são espacialmente incorporadas e multilocalizadas.

Palavras-chave: Organização. Deslocamento. Imigrantes Haitianos. Prática Social.

\begin{abstract}
Inmigración como práctica de organización: discusiones sobre prácticas de organización, desplazamiento e integración de inmigrantes haitianos en la Región Metropolitana de Goiânia, en Goiás, Brasil

\section{Resumen}

Este trabajo busca conducir discusiones sobre las prácticas de desplazamiento y organización, que forman parte del proceso de integración de inmigrantes haitianos en los países en que viven, en su proceso de diáspora. Haiti es un país históricamente caracterizado por el desplazamiento, a ejemplo de las personas que fueron desplazadas por la fuerza para ser esclavizadas en el período colonial del país. Este estudio enfoca el proceso de desplazamiento a través de Estudios Basados en Prácticas y recurriendo a Michel de Certeau, que teoriza sobre prácticas sociales, asociadas a conceptos de Tim Cresswell sobre desplazamiento e inmigración como práctica. La investigación se realizó entre agosto y diciembre de 2017 en dos comunidades haitianas de la Región Metropolitana de Goiânia, estado de Goiás ubicado en el centro-este de Brasil. Para la producción del material empírico, utilizamos las técnicas de historia de vida y observación participante, aplicadas en el seguimiento de las actividades cotidianas de las comunidades de inmigrantes. Como resultado principal se observó que la práctica de desplazamientos de inmigrantes haitianos es un fenómeno cuyo proceso todavía no ha acabado y que ocurre, involucrando diferentes dimensiones de eventos, con los desplazamientos internacional, nacional y pendular. También fue posible concluir que las prácticas de desplazamiento están impregnadas de prácticas organizacionales, siendo el "organizar" y "migrar" procesos envueltos. Además, la práctica de organización es un componente clave para la integración y acceso al lugar de trabajo en Brasil. Así, la inmigración puede ser considerada como un conjunto de prácticas para organizar experiencias de movilidad que son espacialmente incorporadas y multilocalizadas.
\end{abstract}

Palabras clave: Organización. Desplazamiento. Inmigrantes haitianos. Práctica social. 


\section{INTRODUCTION}

The theoretical path that we propose in this article is composed, at first, by the practices, from Michel de Certeau's theory of social practice, as well as the theme of immigration, from the perspective of Tim Cresswell, through the conception of immigration as practices for organizing spatially embodied multilocalized mobility experiences. When working immigration in the field of practice, the view that we build is that mobility/displacement is an action practiced, experienced and embodied, a concept that dissociates the act of immigrating of simply moving for any reason in question (Cresswell, 2006b).

By recognizing the practical dimension of mobility, we will be discussing a concept that is already an important research topic in the area of Administration, which is the field of Practice-Based Studies (PBS). Studies show the theoretical breadth that the concept of practices makes possible for the organizational analyzes, such as the one by Schatzki (2005) about how organizations are constituted, Gherardi's (2010) about human-nonhuman relations in the development and use of telemedicine, Courpasson's (2017) about the emancipation forces of organizational everyday life or the one by Hoof and Boell (2019) about the media in organizations. Specifically in the Brazilian context, there are studies that also highlight the broad scope of the use of the concept of practices in Brazilian organizations, such as the studies by Ribeiro, Ipiranga, Oliveira e Dias (2019) about the "bid aesthetics" of women entrepreneurs, Oliveira and Cavedon (2017) about organizational heterotopies and the one by Junquilho, Almeida and Silva (2012) discussing the practices in the everyday life of school management.

Placing this article in the Practice-Based Studies (PBS), we will bring together the discussions about mobility presented by Cresswell (2006b) with the debates about practices proposed by De Certeau (2014). For De Certeau (2014), space is "a practiced place", a concept that the author initially metaphorizes as the urban scenario, with the street as a geometrically defined place and the pedestrian as the author who transforms the place into space. Thus, we consider that the practices of displacement in the social space constitute immigration in the contemporary urban concept as a place practiced and transformed into space by the immigrants who interact organizationally there.

Oliveira (2014) explains that the Marxist tradition held discussions about immigration, but that these were focused in the understanding of the immigrant as component of an indistinct bloc, in a mostly capitalist analysis, stating that the act of immigrating is due to the desire to accumulate capital. In this sense, this article differs in the analysis by presenting a discussion based on practice.

By considering that this study is part of the administrative sciences of Brazil, with an approach of practice of immigration under the lens of organizational studies, we also present an alternative possibility of producing theories and knowledge about a phenomenon from a point of view of the South (Alcadipani \& Rosa, 2011). If there are social processes that are unique in their occurrence, such as the specific socioeconomic condition of the Southern Hemisphere, it shows that there is a demand for theories produced and applied to different contexts taking into account their specificity.

To operationalize the empirical part of the work, the research subject that we chose was the Haitian immigrant, who is part of one of the most important recent immigration flows in the Brazilian territory, performed by a people that is strongly marked by historical misfortunes. Cotinguiba (2014) affirms that the Haitian situation is contradictory, since the country was one of the greatest achievements of modern history, by the establishment of the first black republic in history and it is the first place to end black slavery in the Americas, but even so its local elite has successfully made efforts to perpetuate some inequalities based on the abolished past.

Our research field includes subjects from Haiti that are established in Brazil. According to the report "Studies about the Haitian Migration to Brazil and Bilateral Dialogue" made by Fernandes and Castro (2014), the emigration movement from Haiti to Brazil began after the earthquake that devastated the country in 2010. Wooding and Moseley-Williams, (2004) state that Haiti is one of the most vulnerable countries in the world to the impacts of hurricanes and tropical storms, in addition to the fact that the country has weak institutions and there is a serious problem of poverty among its inhabitants. All of these aspects of socioeconomic vulnerability contribute to the phenomenon of immigration. Mejía (2015) explains that a quarter of the Haitian population has emigrated mainly because of its economic, political and environmental crisis, which despite of the efforts of solidarity and international humanitarian aid, the country has not experienced real improvements in its living conditions, since only $20 \%$ of its population is employed and the country have a third of its budget from incomes sent by Haitian immigrants established in other countries. 
Between 2010 and 2012 there was an unprecedented inflow of 4,000 Haitian immigrants to the northern region of Brazil (Véran, Noal \& Fainstat, 2014). Brazil became a promising destination due to the country's economic growth discourse at the time, as well as the facilitated possibility of obtaining a visa of permanence (Cotinguiba, 2014). The Haitian immigration, from the point of view of Brazil, has an important representation, because since the Second World War the country has not had such an expressive flow quantitatively of immigrants reaching the country in an irregular situation (Fernandes, 2015).

At the beginning of the immigration flow, Haitian immigrants, upon entering the Brazilian territory, filed a request for refuge with the federal police (Araújo, 2015), claiming that entry to Brazil is due to the poor living conditions in Haiti and because they are unable to find means of subsistence after the earthquake (Fernandes, 2015). However, the Haitian subject was not fully in accordance with the immigration legislation established by the Foreigner Statute, which was in force in Brazil between August of 1980 (period when Brazil was going through the Military Dictatorship) and May of 2017 (when the Immigration Law was instituted). The difficulty in comply the Haitian immigrants in the Refugee Status was due to the fact that Brazil adopted the refugee understanding established in the Geneva Convention of July of 1951, in which it was stablished that the refugee was the person who is outside the country of own nationality and who fears being persecuted for reasons of race, religion, nationality, social group or political opinions. Only with the introduction of the Immigration Law in Brazil is that Haitian immigrants could be included in the humanitarian reception visa ${ }^{1}$

Despite the advances made, according to Silva and Oliveira (2015) Brazil still has a lot to develop in terms of migratory policies, once that currently there is only one regulation that allows immigrants to enter and stay, but there is no solid attention in guaranteeing rights and promoting their integration to the local society. In their study, Cogo and Silva (2016) state that at first the media narratives dealt with the weaknesses of the migratory policies in Brazil in the face of the arrival of Haitians. However, there was a transformation of the "media framework" in the period analyzed. While initially Haitian immigration into the country was interpreted as "flight" from Haiti and "misery", later these pictures were replaced by "Haitian invasion", supporting speeches that defended the need to control the entrance of Haitians (Cogo \& Silva, 2016).

Based on the theoretical framework of this article, our research question is: what are the practices of organization of Haitian immigrants in the Goiânia Metropolitan Region (GMR), in Goiás state? The general objective is therefore to discuss the practices of organization of Haitians who immigrated to the GMR. The choice of this location occurred because the region is one of the most populated areas in the central part of Brazil, but in its recent history had not dealt with an international immigration flow. The empirical research was qualitative and it was conducted between September and October 2017.

The techniques used to produce empirical material were life history interviews and participant observations (Denzin \& Lincoln, 2006). The participant observations occurred in two Haitian immigrant communities with approximately 500 residents overall, resulting in field diaries and photo records that respect the anonymity of the research subjects. These observations occurred in the everyday life activities of these subjects, such as their religious and work practices. The interviews of life story occurred with five Haitians and after the transcription of the interviews there were made analyzes of all the empirical material through interpretative technique, seeking to identify in their speeches their main practices of organization.

The main results of the research indicate that displacement is a continuous practice in the flow of Haitian immigrants and that their integration into society is strongly associated with the relationships established in the community. As a contribution to organizational analysis, we argue that immigration is characterized as a set of practices for organizing spatially embodied and multilocalized mobility experiences.

In terms of the article's structure, we will initially present the theoretical framework, bringing together theories about practices, immigration and deepening of some concepts. Next, we will show the methodological paths adopted for the production of empirical material and the results will be presented intertwined with their respective analyzes. Finally, we will close the article through discussion and concluding remarks.

\footnotetext{
${ }^{1}$ This type of visa had previously been approved by the National Immigration Council (CNIG) and the National Committee for Refugees (CONARE) in Brazil, but initially that kind of visa was granted in a limited way and conditioned to the granting of the State Agencies.
} 


\section{PRACTICE-BASED STUDIES: MICHEL DE CERTEAU'S CONTRIBUTIONS}

Since this is a study that fits into organizational studies, we initially adopted the premise worked by Clegg and Hardy (1996) that organizations are empirical social phenomena, in which each person has a different view when analyzing various aspects of an organization. The meaning adopted here, congruent with the theory of Clegg and Hardy (1996), is that organizations are places of situated social action; open to practices incorporated in the broad social fabric and that can be formalized into disciplinary knowledge. The organizational field, in this case, suggests that there are spaces where the empirical object is constructed, derived from reciprocal interaction and involving a social process (Clegg \& Hardy, 1996).

Moving to the conceptualization of practice, De Certeau (2014) introduces us that subject practices are "ways of doing" and of reformulating organized space through techniques of socio-cultural production. Like De Certeau (2014), we believe that practices are "the ways of doing" and/or "telling" the everyday life performed by social subjects. Everyday life practices can also have a phenomenon of politicization through the use of ingenuity by the weaker in an attempt to take power from the stronger (De Certeau, 2014).

At this point, when dealing with power, the figure of the ordinary man emerges, who according to De Certeau (2014) is the "common hero", "innumerable walker" and "widespread character". The ordinary man, therefore, is the subject present in mass in society, responsible for the operational part of the production sectors, besides being the main consumer of the system. The term ordinary man was presented, at its inception, as a way of naming the individual trajectories that are common to the great mass of society, but due to the authors' ontological and epistemological positioning, we chose to refer to the ordinary man by the term "common person".

Having already presented the common person and the practice as a way of doing it, we stress the need to address the two classifications of practice from two sets of formalities: strategies and tactics (De Certeau, 2014). Firstly, practices strategies are manipulations of force relations that make it possible to isolate subjects of knowledge and power by circumscribing their own places, in which it is possible to manage relationships with an exteriority of targets, such as clients or research objects (De Certeau, 2014).

The rationalization of strategy, in the field of Business Administration, undertakes an attempt to distinguish one's "own" of the environment, that is, a place where one's own will and power manifests itself (De Certeau, 2014). As an example of work in the area, we cite the study carried by Sampaio, Fortunato and Bastos (2013), which sought to evaluate the process of articulation of organizational subjects in the realization of strategies. Another example of work that makes use of the theory of practice in administration is the study by Silva, Carrieri and Souza (2012) that conducted investigations about the creation of practices strategies in organizations through time. There is also the article by Quaresma Júnior, Peixoto and Carrieri (2013) that worked on the everyday life of two cooperatives, monitoring their control strategies and interactions of their members, having their analytical phase supported by tactics theories and inhabited space.

Just as there are practices of a strategic nature that aim temporality for the establishment of one's own, so there are practices that violate the established order. To understand this network of anti-disciplines, of transgression, De Certeau (2014) develops the concept of tactics. Tactics practices are characterized by calculated action that is determined by the absence of one's own and without a place (De Certeau, 2014), where they act in the field of the other and in the space controlled also by the other. As they do not capitalize on temporality, tactics do not establish their own place of action, allowing mobility and improvisation (De Certeau, 2014).

This set of concepts about practices, strategies and tactics, has the effect of understanding another pair of concepts developed by De Certeau (2014) that is space and place. For De Certeau (2014), place is the order in which parts are arranged within coexistence, while space is the effect of these temporally configured orders, resulting in the concept that "space is a practiced place".

Since space is a practiced place composed of parts organized within a coexistence, kinship networks are established as a socially structuring part in everyday life. According to Mayol (2013), the family has identification traits that involve its members through participation resulting from their established values. In this sense, immigrants may have a propensity to structure their social relations based on kinship if they have the presence of their family in the everyday life established in the host country.

In the next part of the article, we will work on the practice of immigration. The practice dimension of mobility that we will adopt is the one defended by Cresswell (2010), which states that movement consists in the accomplishment of something and that practice can be associated with mobility due to the need of making a decision, either that decision is geographical, or at the level of society. 


\section{IMMIGRATION PRACTICE: APPROACHING MICHEL DE CERTEAU AND TIM CRESSWELL}

Initially, Cresswell (2006b) presents that mobility can manifest itself in several ways, such as walking, dancing, running, exercising, moving, traveling or immigrating, our focus phenomenon. Cresswell (2006b) believes that some of these movements may be dissociated from cultural or social characteristics, a thought that deviates from that defended by Michel de Certeau, because for De Certeau (2014) all movement is related to social production. Still, Cresswell (2006a) points out that the movements of people or objects everywhere are full of meanings and may be products or producers of power.

Regarding the conceptual dimension of displacement, Cresswell (2006b) describes three basic forms of immigration. The first form of displacement is characterized by the displacement of people from their cities during the day to perform professional and student activities in other cities, also known as commuting displacement (or immigration) (Cresswell, 2006b). The second, national migration, is the internal mobility within the geographical area of a country (Cresswell, 2006b). The third form, which is part of the focus of this article, concerns international mobility, in which there are displacements between different National States (Cresswell, 2006b).

In the case of international immigration, Cresswell and Merriman (2010) state that these subjects are regularly represented in the media as poor, uneducated and non-white, and they are taken as "drains" of State services. However, discourses in this sense not only neglect the complex histories and geographies of migration, but also disregard the diversity of subjects who assumed the position of immigrants (Cresswell \& Merriman, 2010). Mezzadra and Neilson (2013) state that the matter of borders itself, which is a constitutive part of the phenomenon of immigration, has a cognitive dimension of existence that structures the movement, demonstrating the existence of different aspects related to immigration, such as temporal, social and political aspects. In this sense, the debate of immigration as practice addresses a dimension of displacement based on a social perspective.

According to Cresswell (2006b) immigration should be seen as mobility, and mobility, like displacement, is practiced, experienced and embodied, so migrating is no longer simply fleeing for political or economic reasons. Thus, the fact that subjects usually experience mobility and the way people move are closely connected to the meanings given to mobility through representation, as well as mobility representations are based on the way that mobility is practiced and incorporated (Cresswell, 2006b).

For Cresswell (2010), the practice is commonly confused with mobility, since the act of moving results in the process of doing something. Cresswell (2010) affirms that when moving, decision-making is required, which is subject to geographical and societal constraints. The practices embodied in the process of world experimentation create spaces and stories, and these stories are classified as space stories. These practices, for Cresswell (2010), also involve several concrete commitments, requiring a variety of technologies and infrastructure.

When performing the displacement between places, Cresswell (2006a) states that it is possible to think of movement as abstract mobility, in which there is abstraction of power contexts. Motion is composed of time and space, once, according to Cresswell (2006b), motion is the spatialization of time and temporalization of space. For Cresswell (2005), space is a more abstract concept than place, since space has areas and volumes; and places have space between them.

In this sense, Cresswell (2005) says that places are never finished, for the reason that they are the result of processes and practices and they are constantly in performances. Thus, immigration in manifestation can influence your host location through your practices beyond the time of establishment. A practical example are cosmopolitan cities that present in their material landscapes characteristics of the ethnic groups that settled there.

One field that has approached immigration in Administration is entrepreneurship. Examples in this area include the articles by Silva and Yen-Tsang (2015), Mariz and Bógus (2013) and Oliveira (2007) that studied immigrant enterprises in Brazil. Studies about entrepreneurship by immigrants are under development by legislators and researchers, especially in Europe, where, according to Hammarstedt (2004), entrepreneurship is an important way of assimilating immigrants.

In short, the theoretical contribution of this article is the approximation of the theories of Michel de Certeau and Tim Cresswell, considering that mobility is a social phenomenon to be practiced, performed and that constantly influences its environment through time in the geographic space in which it occurs. In this sense, it is possible to understand immigration as practices of organizing spatially embodied multilocalized mobility experiences 


\section{METHODOLOGICAL PATHS}

In this article, the empirical strategy that we adopted has a qualitative nature, and its use is justified in order to try to understand and explain a social phenomenon. As for the purposes, the work is descriptive and explanatory, since it already exists debates about Haitian immigration, but we seek to explain how the phenomenon of practices of organization of Haitian immigration in Brazil occurs. To this end, we use the techniques of participant observation and life story interview to produce the empirical material.

We sought to understand how the organization of Haitian subjects as immigrants occurs in Brazil, and therefore qualitative research allowed us to go to the field to capture the phenomenon from the perspectives of the people involved in it (Godoy, 1995). The purpose of the empirical production of this work is to seek to understand the experiences lived in the organizational process of the researched subjects, always bearing in mind that no method is able to collect all variations of the continued human experience, but individuals can offer reports of their actions (Denzin \& Lincoln, 2006).

The geographic locus chosen was the Goiânia Metropolitan Region (GMR) because it highlights how Haitians have been organized in the Midwest region of Brazil. According to Complementary Law 27 of December 30, 1999, the Goiânia Metropolitan Region comprises eleven municipalities, namely: Abadia de Goiás, Aparecida de Goiânia, Aragoiânia, Goiânia, Goianápolis, Goianira, Hidrolândia, Nerópolis, Santo Antônio de Goiás, Senador Canedo and Trindade.

In order to seek a first access to the field and, consequently, to be able to understand the current dimension of manifestation of the phenomenon of immigration of Haitian subjects in the GMR, we searched for a field entrance door within the university itself. It was at this point that we discovered that there was a mapping work of these subjects being conducted by some researchers from the Federal University of Goiás. We contacted the responsible professor and we received the contact of Pastor Ali2 ${ }^{2}$ person responsible for the Expansul Methodist Church, main meeting point of the community's Haitians.

Simultaneously to the initial attempts of contact within the educational institution, we contacted the Goiânia Immigrant Pastoral Service, which is headquartered at the Goiânia Interstate Bus Station, sending an e-mail that explained our research. Our contact was promptly answered by Sister Maria, who invited us to attend the meeting of the Interreligious Group (IR Group), in which would be discussed about the return of activities with the Haitian immigrants. This meeting would take place in the following Saturday morning at Pastor Ali's house.

The IR Group is a group of people of different religions, founded in October of 2015, under the organization of Sister Maria and Pastor Ali. The main focus of the group is to support Haitian subjects established in the GMR, however, they also provide assistance to refugees (mostly Syrians and Venezuelans).

On August 5, 2017, we had the first visit to the field in order to attend the meeting, where we found out that there are two Haitian Communities in the Region, the Expansul Community and the Guanabara Community. The number of Haitians in the Expansul neighborhood was provided by Pastor Ali, with an estimated presence of approximately 1,000 Haitians in Aparecida de Goiânia and 3,500 in the state of Goiás. We emphasize that there is a difficulty in making an accurate calculation of how many Haitians live the region, because many Haitians are still involved in migratory flows in search of job opportunities and not all the Haitian immigrants are involved in the communities of the region.

Having this first contact with the field, we were able to start our participation in their everyday life activities, focusing mainly on the moments of interactions of the Haitian subjects. In all, we made 18 field visits from September to October of 2017, attending church services in both communities, IR Group meetings, graduation ceremonies of professional courses in both communities, a wedding reception at Guanabara Community, a Farewell party of a Haitian who was emigrating, Portuguese classes in both communities and a routine day in a Haitian household in the Expansul community.

Based on these observations, we also chose to conduct life story interviews so that the research subjects could produce a narrative about their subjective constitution, considering that the observations have as characteristics the understanding of social phenomena, even if historical, circumscribed to a specific space-time relationship. The interviews were

${ }^{2}$ All the names of the subjects involved in the research have been changed to ensure their anonymity. 
conducted with five Haitian people who live in the community (Box 1), and the criteria used for them to be interviewed was to have the condition of Haitian immigrant in Brazil and have an active participation in the everyday life activities of the community.

Portuguese, French and English were the languages used to conduct the research. In the informal conversations during the field period, the three languages converged in the conversations, but we could notice that although French is one of the official languages of the country, the language is not considered as "home language", and this classification belongs to Haitian Creole. In the interviews, the predominant language was Portuguese, but when the interviewees found it difficult to express themselves, we resorted to other languages to achieve understanding.

\section{Box 1}

Sociodemographic Characteristics of the Interviewees

\begin{tabular}{|c|c|c|c|c|c|c|}
\hline Interviewee & Gender & Profission & Age & Community & Marital status & Period in Brazil \\
\hline 1- Fabienne & Female & Unemployed & 19 & Expansul & Single & 8 months \\
\hline 2- Joel & Male & Loader & 38 & Expansul & Married & 2 years \\
\hline 3- Cedric & Male & Graphics Assistant & 23 & Guanabara & Married & 1 years \\
\hline 4- Benjamin & Male & Loader & 32 & Guanabara & Married & 4 years \\
\hline 5- Adonia & Female & Fruit Selector & 31 & Guanabara & Married & 3 years \\
\hline
\end{tabular}

Source: Elaborated by the authors.

To ensure the validity of the techniques employed, we sought to perform the triangulation technique (Oliveira \& Piccinini, 2009). The triangulation was intended to combine the emic (what happens in the field), the ethical (the researcher's experience in the field) and the theoretical (theorizing mobility as a social practice), thus seeking to establish reliability in qualitative research. The research design was submitted and approved by the board of ethics in research at the Federal University of Goiás.

Finally, after the stage of interviews and participant observations, we performed the analysis of the empirical material through the understanding of the phenomenon in a comprehensive interpretative way. Interpretative analysis sought to understand, through interpretation, the meanings, proposals and intentions that people give to their own actions and interactions with others (Smith, 2008). To support the interpretation of the results, field diaries, photos, and videos of the interactional moments were used. Cavedon (2014) shows us that the researcher's personal aspects can be recorded in field diaries, thus aiding future reflections and ethical understanding by researchers.

\section{PATHS OF HAITIAN IMMIGRATION IN BRAZIL}

In this topic, in which we will focus on presenting and analyzing the findings of the field, we will make in the text an attempt to metaphorize the journey of the Haitian subjects in their migratory process as "paths" traveled. Our decision to approach the analysis in this way was triggered by the discovery that some Haitian immigrants from the Expansul Community have to walk nearly 43 kilometers a day, on a weekend basis, to and from work in the Hippie Fair of Goiânia. The Hippie Fair is a special fair that traditionally took place every Sunday at Worker's Square, near the Goiânia Interstate Bus Station, but currently takes place from Fridays to Sundays. Some Haitians find in this fair an alternative form of subsistence, in response to unemployment, acting mainly in two ways: freelance employees, being paid by other traders per day worked or as informal entrepreneurs, selling their goods as street vendors.

As reported in the introduction, the results and their respective analyzes will be presented together on this topic for better fluidity of excerpts from life story interviews with the theory and empirical content of other natures that were produced and incorporated into the analysis. 


\section{“OPEN THE PASS WAY FOR ME TO PASS"3: FROM HAITI TO BRAZIL}

"My father and mother left the country in 2010 to go there in Venezuela. I stayed in Haiti, me, my sister and my brother. After I finished my study, my mother came to pick me up. And I'm here" (Fabienne, September 2017).

In its history, Haiti has experienced many misadventures that led it to become a country of emigration, with some countries on the American continent forming part of the experience of Haitian immigration as destination territories. The countries of Latin America have been poles of reception for Haitian immigrants throughout history, being part of the Haitian Diaspora (Ávila, 2016), mainly due to the ease of access, both in terms of displacement and in the process of entry.

In addition, there is another important factor to consider in relation to the Haitian diaspora in the American continent: the power of networks in this transnational immigration process (Cotinguiba, 2019). For Cotinguiba (2019), the family constitutes structural elements of Haitian mobility and mobility is a structural element of Haitian society. Thus, the fact that Haitians immigrated previously to Latin American countries may have been one of the reasons why the current flows of Haitian immigration occur towards these countries, in which the established networks facilitate the practice of immigration.

Thus, we approach Mayol's (2013) assertion about kinship relationships being socially structuring when analyzing the power of networks in the process of immigration, based on the identification of subjects by the values established in the social environment through participation. By theoretical generalization, it is possible to affirm that in addition to the family, in the case of immigration, the other ties established with other immigrants who came from the same country also generate participation through identification, although not to the same degree as in the family relations. This is because it is the social and affective bonds within this population that makes it possible to establish a transnational social space of mobility between them beyond the borders between countries.

At this point, we validate through this work the finding of other researchers regarding the path to Haitian international immigration, and three of our five respondents (Benjamin, Joel and Adonia) were immigrants in other countries (Dominican Republic and Nicaragua) before reaching the Brazilian territory. These previous experiences were found during the production of empirical material, when some of the immigrants unable to speak Portuguese resorted to English and Spanish to make themselves intelligible to the researchers.

"When I lived there in Haiti, when I was a kid, my age was not working and I was too young to work, but it was because I was dating, then another life, then we went, decided and already moved. We lived in the Dominican Republic a long time ago, live there and that was the rest of my Haitian history. I went to Haiti for a while; the rest was there in the Dominican Republic" (Adonia, September 2017).

However, a differential that arises at the moment is that now the immigration flow to Brazil is undergoing a structural change, because two of the five interviewees came legally (Fabienne and Cedric), having the authorization for legal immigration previously acquired in Haiti. These two cases found in interviews pluralize each other as Fabienne came with her brother, both already with visas, to meet their parents that had been in Brazil for two years, while Cedric made the decision to immigrate with his fiancée and both were hosted by relatives already established in Brazil. In the case of Cedric, he has the desire to settle in Brazil and bring his family, since he sees better prospects of achieving his personal ambitions.

It is in this sense that De Certeau (2014) states that practices produce social spaces. For Haitian immigrants, one singularity of their spatial "ways of doing" is the family ties (Cotinguiba, 2019). Practicing your family ties implies spatializing your collective constitution based on the principle of mobility of transnational social spaces even if family ties have traditionally been considered as practices of place production, in the sense of "fixing" subjects into a space and time relationship, usually linked to a physical place. In the case of Haitian immigration, this process seems to happen in the opposite direction, which highlights the need to consider historical and contextual elements to discuss organizational practices.

Another important point is the need to consider the mobility of social subjects as a basis for analyzing transnational organizational processes in addition to the practices of economic transactions. In the case analyzed, despite being an

${ }^{3}$ We paraphrased excerpts from the song Fio de Prumo (Padê Onã) sang by Criolo with the participation of Juçara Marçal in the titles of the topics of the results analysis. 
important dimension of organizational mobility for Haitians, the links within this population make this mobility possible. That is, as Cotinguiba (2019) argues, mobility is a structural practice of Haitian society, consequently, of its way of organizing beyond geographical borders.

However, it should be noted that the international path of Haitian immigrants is not over. During the research period, we got to know about a family of Haitians who were immigrating to French Guiana to meet up with their relatives who live there. In addition, the insecurity generated by their immigrant status reinforces the sense of non-territorialization of these subjects within the Brazilian geographic space. Indeed, the practice of Haitian immigration does not only occur on the way to Brazil, but also within the country as a way of producing or finding a place where this insecurity is mitigated in economic, political or cultural terms, which will be discussed in next subsection of this article.

\section{“BEND THE STRENGTH OF THE ARMS”, I WILL WALK THROUGH BRAZIL}

"I went there in Santa Catarina. Alas, when I got there, I could not find service. Then I leave Santa Catarina and come here" (Joel, September 2017).

In this topic, we will address the path that Haitian immigrants take within Brazil until settling in the GMR. National migration is the second basic form of migration, according to Cresswell (2006b), which consists of internal mobility within a country's territory. Four of the interviewed subjects (Adonia, Joel, Cedric and Benjamin) took this path within Brazil. In general, during the field period, we noticed that most of the Haitian immigrants were in other cities, usually in border regions, before settling in the GMR, some being welcomed by friends or relatives, but eventually emigrating again in search of better opportunities.

According to Araújo (2015), Haitian immigrants also had cities on the borders of Brazil as transitory representations, since the small cities of the border regions did not have enough space in the local labor market to integrate the number of immigrants who arrived after 2010. Another reason for the path taken in the national territory is to be close to relatives who are already in other states of Brazil. Ávila (2016) reports in his study that the decision for immigration has a strong connection with their affective bonds, since immigrants perform communicative practices between their friends and family during the process, mainly mediated through technologies, evidencing again the network power in the immigration phenomena.

"Why Goiânia? Because I have my friend who live here, he said how is Goiania, how is work, all this, so I decided to come here" (Cedric, September 2017).

Thus, communicative practices are associated with mobility practices especially on the national path, because respondents reported that the decision for international migration occurred mainly due to the imagery built in Haiti about Brazil, although the presence of friends and family in the country also influences the process. For national immigration, the affective ties were more present, often enabling Haitians to move around with job prospects previously arranged by their acquaintances. This fact reinforces the power of kinship's network in deciding and constituting immigration spaces, as highlighted by Cotinguiba (2019).

In addition, it is possible to articulate this discussion with the notion of social action by Weber (2004), when this author states that the communicative process between individuals can be considered as a social action, as its meaning refers to the behavior of others, guiding up for this in your course. Being able to be determined in an affective way, social action, characterized here as a communicative practice, guides the processes of interactions between Haitians, this being one of the practices that produces meaning for their mobility.

"I worked, lived in Porto Velho and then I started working, I had a person closer to us, friendship, she called me and then I got a job and then I came to live with them, then we are here so far" (Adonia, September 2017). 
Another explanation for why these immigrants made use of national immigration is the matter of borders. When they were able to file a request for refuge, the first immigrants obtained permission for the issuance of the Individual Taxpayer Registration (CPF) and the Work Document (Araújo, 2015), thus being able to transit legally within the Brazilian territory during the granting period. Nonetheless, there are other frontiers that this population needs to cross.

Cresswell (2005) shows us that the delimitation of borders is a way of differentiating a particular region, from others around it, however, just as there is the delimitation of borders from a geographical point of view, De Certeau (2014) also addresses the existence social boundaries or limits, as part of a practice of power, involving the territory through the concept of "appropriate place". Associated to the practice of power, strategic practices are a strong weapon for classification, mapping, delineation and division (De Certeau, 2014). In this sense, legal boundaries, which can be practice of strategy in order to classify the "type of desirable immigrant", constitute one of the main limitations for the Haitian population to practice in their everyday life in the host country so that they can integrate and transform this space into place, that is, appropriating Brazilian spaces so that they become their homes.

The Brazilian law places different frontiers that become the crossroads of the possibilities of this population to reach the country. When arriving in Brazil, the Haitian subjects are faced with a "nation of many contradictions", both in politics, as in social and economic, being bureaucratic and slow the process of regularizing the immigration (Rodrigues \& Marchese, 2016). These immigrants, who were destitute, found it difficult to obtain social assistance and access to public policies (Rodrigues \& Marchese, 2016). Even if the regularization process ended successfully, these subjects still remained with the challenge of integrating into society, leading many Haitians to become discouraged and give up on the Brazilian dream, leaving the country for new immigration routes (Rodrigues \& Marchese, 2016).

Therefore, national displacement is a way of overcoming the difficulties that the immigrant faces after the international immigration and, in this sense, an attraction of the GMR for the Haitians already in Brazil was the growth of the immigrant community in the region. It is reported by some Haitians during the field period that the fact that there is a place with the possibility of participating in cults in Haitian Creole language and that they can live near work (in the Guanabara Community) represents a major differential. Such appreciation of these specificities is due to the church having a great symbolic value for Haitian subjects, as it increases their sense of acceptance. Given this, we can say that integration into society can also occur locally, in which Haitian immigrants gather and move to places close to their community, generating integration in a regional context.

\section{“CONCRETE INFECT WALLS”: ON THE WAY OF WORK AND LEISURE}

"There was no time for us to walk, because work already takes all the time right? Only then on Sunday. Saturday I work all day, on Sunday I also go to church and only for the afternoon, only, there is no time to walk" (Benjamin, September 2017).

The path of this topic corresponds to displacement between cities and commuting mobility is the third and last basic form of displacement pointed out by Cresswell (2006b), in which there is commuting during the day to perform their professional and student activities in other cities. In this case, we have expanded the theory so that it also encompasses displacement for leisure purposes. The choice to frame leisure displacement as commuting is because the two GMR's Haitian communities are in peripheral regions of the cities, thus there are not many leisure options locally for their days off work.

In the case of subjects who walk to work at the Hippie Fair of Goiania, mobility is mainly through walking, since these subjects are unemployed and their income from informal activities does not offer enough value for using public transportation. De Certeau (2014) states that walking activity is characterized by lack of place and is part of the indefinite process of existing and seeking one's own. Immigrants on their journey to the place of their financial activities are endowed with an indefinite sense of their existence. In addition, the road gives you great physical insecurity, as much of the stretch is also traversed by the highway BR-153, in which they walk among the lawns that divide the roads.

In this context, it is possible to consider the coexistence of different mobility practices in the constitution of the Haitians' organizational space. This population continues not only maintaining mobility as a structuring factor in its organizational 
constitution, like in this case due to economic conditions, which results in its constant transit between the cities of the GMR, but it also evidences how Brazilian cities are not thought for the people. De Certeau (2014) states that the concept cities are designed not to be inhabited by the subjects, but to fix them. Thus, when people need to walk through these cities, they need to create new routes, detours, so that it is possible to live in these locations. In relation to the practices of displacement of Haitians on the highways, this is very evident, insofar as their own life are put at risk in the coexistence of walkers with the traffic of cars, without the infrastructures of sidewalks. Therefore, for a people that has mobility in its structural elements of constitution (Cotinguiba, 2019), walking is one of its main practices of resisting the economic conditions imposed to them.

As for mobility for leisure purposes, one of our main findings is that Haitians prefer not to move to other parts of cities when they have free time. This decision is mainly due to their arduous work routines, their financial constraints and the GMR's urban violence. Violence represents a paradox, since there is a reversal of representations. While immigrants are considered transgressors (Cogo \& Silva, 2016), because they establish themselves in a space that is "not theirs", immigrants also occupy a position of double vulnerability. This doubly vulnerable condition is because these immigrants, besides being deterritorized in a situation of wealth not shared among the inhabitants of the country, they also end up sharing violence with the nationals. Such conditions of shared violence are related to the structural issue of the city, where masses located in peripheral areas are more exposed to urban violence.

"Saturday like today I went to (the mall) Flamboyant. I wait for bus at the point, then a thief passed and take rifle and mug. But there are a lot of Brazilians who are very good. There are a few that do that" (Joel, September 2017).

Therefore, their leisure activities are placed on the other everyday life practices that are capable of performing productions without time domination (De Certeau, 2014), such as visiting their friends who live nearby or attending to the church, since the church was pointed by the immigrants as its main source of leisure. For the most part, for Haitians immigrants in the GMR, walking around the city means to walk towards work.

\section{“AND THE FOLDING OF THE WORKER'S BACK ON THE STREET": ECONOMIC SITUATION}

Regarding work, during the researchers' first field visits, in three situations, Haitian subjects approached us asking for helping them in finding a job, while in two other situations we have been asked to help their acquaintances find a job. Through participant observations and interviews, it was possible to realize that social capital ${ }^{4}$ among Haitian subjects in their communities represents an important component of subsistence-related practices.

"My friend there told me: there is a person there who needs someone to work in a print shop. He talked like that and after he sent his phone, I talked to him and then I went there for an interview" (Cedric, September 2017).

In the case of the interviewed subjects, four of them had formal jobs, which are also framed within the strategies practices, because in the formal work there is the manipulation of power relations made possible from the moment when a subject of will and power can be isolated, besides postulating the strategy as a place where it can be demarcated as something that can manage relationships through the externalization of targets or threats (De Certeau, 2014). However, most of the jobs that the subjects got demands a lot of physical effort, fact that makes some Haitians unhappy with their positions, associated with no prospects for growth of their career. In some cases, during the research, it was shared with us their desire of being able to study, but their heavy routines, which often require night work, exhaust them.

This relationship of Haitians with work in Brazil also highlights how the labor market in the country is structured. Although these subjects are technically qualified to perform functions other than operational, this is the place (De Certeau, 2014) socially

\footnotetext{
${ }^{4}$ Social capital is a concept that was first presented by Bourdieu, and according to Portes and Sensenbrenner (1993) the social capital corresponds to the expectations of action of a collectivity and that affects the economic objectives and the behaviors of its members in the pursuit of objectives, even in the circumstances of these expectations not being directly oriented towards an economic sphere.
} 
intended for them. It is then necessary to relate the immigrant social category with other social categories to understand this process. As Diehl (2016) points out, although Brazilians develop an empathy towards foreigners, this process occurs when they originate predominantly from Europe or North America. In relation to Latinos, this empathy of Brazilians is many times absent and when related to the race category, as the Haitians are mostly black people, the condition of black immigrants becomes another challenge for them in the Brazilian labor market.

\section{DISCUSSIONS AND FINAL CONSIDERATIONS}

We argue in this article that immigration can be considered as sets of practices for organizing spatially embodied multilocalized mobility experiences. Considering immigration as a practiced process, we emphasize that beyond the economic motivations, there is a dimension of building experiences of space and time relations, produced in different localities and articulated in specific contexts, which must be considered and that are the basis of the organization of immigrants. In this regard, this is the first dimension of the theoretical argument that we present by highlighting an approximation between the debates proposed by Michel de Certeau about practices and Tim Cresswell about immigration to understand the immigration process as multilocalized social experiences.

Thus, a first contribution to the field of Administration that we present is the deconstruction of the understanding of migration as a phenomenon centered on economic dimensions to consider it as a political phenomenon, based on the propositions of Tim Cresswell. Indeed, it was possible to approximate these discussions with the debates presented by Michel de Certeau, because this author highlights the need to understand the political dimension of everyday life also in organizations.

Figure 1

Practices of Organization of the Haitian Immigrants

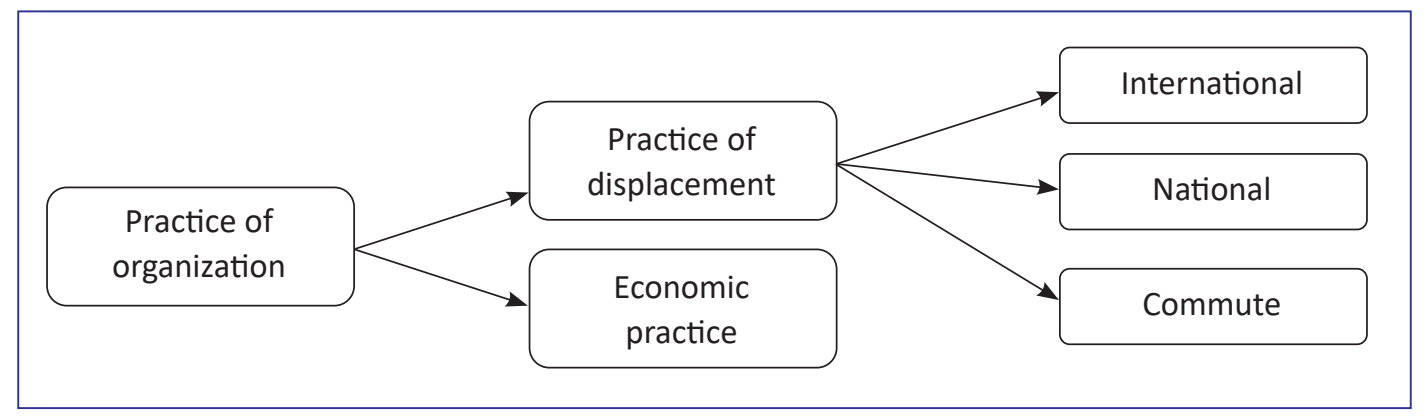

Source: Elaborated by the authors.

About the results (Figure 1), the first practice that we present is the practice of displacement, which together with the economic practice are part of the practices of organization that we could apprehend in the research with the Haitian Immigrants. We present the practice of displacement in three levels of occurrence, taking into account the basic forms of immigration (Cresswell, 2006b): international, national and commuting. In the international displacement practices, we discussed about how the immigration path between Haiti and Brazil took place. At the beginning, it happened through under a refugee status but in the most recent arrivals, the Haitian immigrants are coming legally to Brazil in search of better living conditions, under the humanitarian visa scheme. In the national practices, we point out that once inside the country, Haitians move mainly in search of economic opportunities and to be closer to their friends/relatives, being that practice related to the economic practice and to the power of social networks.

In the commuting practices, it was found that immigrants from the GMR mainly take their path to work by bicycle or by foot and they do not show willingness/possibility to go out on their days off for various reasons (tiredness, lack of money and urban violence). Paradoxically, during this research we also found that immigrant subjects, who traveled long distances to Brazil, are currently in a situation of mobility hampered by the social system to which they are inserted. The distances of GMR's two communities from each other and from their respective communities to the city's leisure and 
trade hubs represent a structural barrier, erected in the urban context, which makes Haitian immigrants more distant from greater options of work and leisure.

Regarding the economic situation of Haitian immigrants, we found that Haitians in the region usually occupy heavy-duty positions, with low wages in return, besides the exploitation of labor, which fits the economic practice into the strategy practices (De Certeau, 2014). In the field of Administration, the results found in economic practice are a warning regarding the labor relations between immigrants and Brazilian employers, and it is appropriate to rethink the forms of hiring and insertion of immigrants into the local labor market. All these aspects that involve organizational practices are components of the integration process of these subjects in their everyday life in Brazil.

Thus, future research may also deepen the discussions presented here, for example, in terms of gender, as we observe that there are gender divisions in Haitian communities that, due to the theoretical and methodological choice of work, were not discussed in this study. Women are usually assigned to the home and caring tasks, while men are assigned to be primarily responsible for household finances, even if both men and women have paid work positions.

Finally, the discussions we have promoted in this article have been established in the field of Practice-Based Studies through the practices of organization of one of the largest flows of immigration in recent Brazilian history. We conclude this work by presenting a conceptually worked out view of the immigrant organization, dissociated from the discussion of a capitalist economic essentialism, which also represents a theoretical contribution to the field of Administration.

\section{ACKNOWLEDGEMENTS}

This study was financed in part by the Coordenação de Aperfeiçoamento de Pessoal de Nível Superior - Brasil (CAPES) Finance Code 001. 


\section{REFERENCES}

Alcadipani, R., \& Rosa, A. (2011). From grobal management to glocal management: Latin American perspectives as a counter-dominant management epistemology. Canadian Journal of Administrative Sciences/Revue Canadienne des Sciences de l'Administration, 28(4), 453-466.

Araújo, A. (2015). Reve de Brezil: a inserção de um grupo de imigrantes haitianos em Santo André, São Paulo-Brasil (Masther Thesis). Universidade Federal do ABC, Santo André, SP.

Ávila, O. C. (2016). O Haiti em Curitiba: um olhar interpretativo das práticas comunicativas dos haitianos no novo território (Masther Thesis). Universidade Federal do Paraná, Curitiba, PR.

Cavedon, N. R. (2014). Método etnográfico: da etnografia clássica às pesquisas contemporâneas. In E. M. Souza (Org.), Metodologias e analíticas qualitativas em pesquisa organizacional: uma abordagem teórico-conceitual (pp. 65-90). Vitória, ES: EDUFES.

Clegg, S., \& Hardy, C. (1996). Organizations, organization and organizing. In S. CLEGG, S., \& C. HARDY (Eds.), Handbook of organization studies (pp. 1-28). Thousand Oaks, CA: Sage.

Cogo, D., \& Silva, T. (2016). Entre a fuga e a invasão: alteridade e cidadania da imigração haitiana na mídia brasileira/Between escape and invasion: otherness and citizenship of Haitian immigration in the Brazilian media. Revista FAMECOS, 23(1), 1-18.

Cotinguiba, G. C. (2014). Imigração haitiana para o Brasil: a relação entre trabalho e processos migratórios (Masther Thesis). Fundação Universidade Federal de Rondônia, Porto Velho, RO.

Cotinguiba, G. C. (2019). Aletranje: a pertinência da família na ampliação do espaço social transnacional haitiano - o Brasil como uma nova baz (Doctoral Dissertation). Universidade Federal de Rondônia, Porto Velho, RO.

Courpasson, D. (2017). The politics of everyday. Organization Studies, 38(6), 843-859.

Cresswell, T. (2005). Place: an introduction. Nova Jersey, NJ: John Wiley \& Sons.

Cresswell, T. (2006a). On the move: Mobility in the modern western world. London, UK: Taylor \& Francis.

Cresswell, T. (2006b). The right to mobility: the production of mobility in the courtroom. Antipode, 38(4), 735-754.

Cresswell, T. (2010). In place-out of place: geography, ideology, and transgression. Minneapolis, Minnesota: University of Minnesota Press.

Cresswell, T., \& Merriman, P. (2010). Geographies of mobilities: Practices, spaces, subjects. Farnham: Ashgate Publishing, Ltd.

De Certeau, M. (2014). A invenção do cotidiano: 1 Artes de fazer. Petrópolis, RJ: Ed. Vozes.

Denzin, N., \& Lincoln, Y. (2006). O planejamento da pesquisa qualitativa: teoria e abordagens. Porto Alegre, RS: Artmed.

Diehl, F. (2016). As ressignificações do conceito de raça e o racismo contra os imigrantes haitianos no Brasil. In Anais do 13 Seminário Internacional de demandas Sociais e Políticas Públicas na Sociedade Contemporânea, Santa Catarina, SC.
Fernandes, D. O. (2015). Brasil e a migração internacional no século XXI: notas introdutórias. In E. J. P. Prado, \& R. Coelho (Orgs.), Migrações e trabalho. Brasília, DF: Ministério Público do Trabalho.

Fernandes, D., \& Castro, M. C. G. (2014). Estudos sobre a migração haitiana ao Brasil e diálogo bilateral. Belo Horizonte, MG: Organização Internacional das Migrações, 2014.

Gherardi, S. (2010). Telemedicine: A practice-based approach to technology. Human relations, 63(4), 501-524.

Godoy, A. (1995). Pesquisa qualitativa: tipos fundamentais. Revista de Administração de empresas, 35(3), 20-29.

Hammarstedt, M. (2004). Self-employment among immigrants in Sweden-an analysis of intragroup differences. Small Business Economics, 23(2), 115-126.

Hoof, F., \& Boell, S. (2019). Culture, technology, and process in 'media theories': Toward a shift in the understanding of media in organizational research. Organization, 26(5), 636-654.

Junquilho, G., Almeida, R., \& Silva, A. (2012). As "artes do fazer" gestão na escola pública: uma proposta de estudo. Cadernos EBAPE.BR, 10(2), 329-356.

Mariz, M., \& Bógus, L. (2013). Empreendedorismo Feminino: Imigrantes portuguesas em São Paulo. Brasiliana - Journal for Brazilian Studies, 2(2), 477-505.

Mayol, P. (2013). Morar. In M. De Certeau, L. Giard, \& P. Mayol (Eds.), A invenção do Cotidiano (Vol. 2, pp. 35-185). Petrópolis, RJ: Editora Vozes.

Mejía, M. R. G. (2015). Relato da experiência migratória de mulheres haitianas no Sul do Brasil. In Anais do 13 Congreso Latinoamericano de Antropología, Florianopolis, SC.

Mezzadra, S., \& Neilson, B. (2013). Border as Method, or, the Multiplication of Labor. Durham, North Carolina: Duke University Press.

Oliveira, J. (2007). Empreendedorismo Sem Fronteira: desafios e conquistas dos imigrantes chineses no Brasil. In Anais do $31^{\circ}$ Encontro da ANPAD, Rio de Janeiro, RJ.

Oliveira, J., \& Cavedon, N. (2017). Os Circos Contemporâneos como Heterotopias Organizacionais: Uma Etnografia Multissituada no Contexto Brasil-Canadá. RAC-Revista de Administração Contemporânea, 21(2), 142-162.

Oliveira, M. (2014). O tema da imigração na sociologia clássica. DadosRevista de Ciências Sociais, 57(1), 73-100.

Oliveira, S., \& Piccinini, V. (2009). Validade e reflexividade na pesquisa qualitativa. Cadernos EBAPE.BR, 1(7), 88-98.

Portes, A., \& Sensenbrenner, J. (1993). Embeddedness and immigration: Notes on the social determinants of economic action. American journal of sociology, 98(6), 1320-1350.

Quaresma, E. A., Jr., Peixoto, D., \& Carrieri, A. (2013). A cristalização de uma microrrevolução francesa: o caso das cooperativas de Salinas-MG. RAM - Revista de Administração Mackenzie, 14(6), 162-184. 
Ribeiro, R. C. L., Ipiranga, A. S. R., Oliveira, F. F. T. D., \& Dias, A. D. (2019). Uma "estética de lances" de uma "heroína ordinária": o reorganizar de práticas de resistências de uma artesã. Cadernos EBAPE.BR, 17(3), 590-606.

Rodrigues, V. M., \& Marchese, V. F. (2016). Migração haitiana para o Brasil: problemática e perspectivas. Acesso Livre, 5, 106-124.

Sampaio, I., Fortunato, G., \& Bastos, S. (2013). A estratégia como prática social: o pensar e o agir em um programa social governamental. Organizações \& Sociedade, 20(66), 479-499.

Schatzki, T. (2005). Peripheral vision: The sites of organizations. Organization studies, 26(3), 465-484.

Silva, A., Carrieri, A., \& Souza, E. M. (2012). A constructionist approach for the study of strategy as social practice. BAR-Brazilian Administration Review, 9(esp), 1-18.
Silva, C., \& Yen-Tsang C. (2015). Tem Comida Chinesa no Prato dos Brasileiros: Como Empreendem os Imigrantes Chineses no Brasil. In Anais do 39o Encontro da ANPAD, Maringá, PR.

Silva, J., \& Oliveira, M. (2015). Migrações, fronteiras e direitos na Amazônia. REMHU: Revista Interdisciplinar da Mobilidade Humana, 23(44), 157-169.

Smith, J. (2008). Interpretative Inquiry. In L. Given, L. (Ed.), The Sage encyclopedia of qualitative research methods. London, UK: Sage Publications.

Véran, J., Noal, D. S., \& Fainstat, T. (2014). Nem refugiados, nem migrantes: a chegada dos haitianos à cidade de Tabatinga (Amazonas). Revista Dados, 57(4), 1007-1041.

Weber, M. (2004). Economia e sociedade. Brasília, DF: UnB.

Wooding, B., \& Moseley-WilliamS, R. (2004). Needed but unwanted. London, UK: Catholic Institute for International Relations, 2004.

Gabriel do Carmo Yamamoto ORCID: https://orcid.org/0000-0002-3165-8409

Master in Administration from the Federal University of Goiás (PPGADM/UFG); Ph.D. Candidate in the Graduate Program in Administration at the State University of Maringá (PPA/UEM); Guest Ph.D. Student in the Danish School of Education at Aarhus University (DPU/AU), Copenhagen - Denmark. E-mail: gabrielyamamoto@gmail.com

Josiane Silva de Oliveira ORCID: https://orcid.org/0000-0002-7085-8921

Ph.D. in Administration from the Federal University of Rio Grande do Sul (PPGA/UFRGS); Adjunct professor in the Department of Administration at the State University of Maringá (DAD/UEM); Researcher in the Center of Afro-Brazilian Interdisciplinary Studies at the State University of Maringá (NEIAB/UEM), Maringá - PR, Brazil. E-mail: oliveira.josianesilva@gmail.com 